The Creative Writing Handbook 


\section{The Creative Writing Handbook}

Techniques for New

Writers

Edited by

John Singleton and

Mary LuCKhuRst 
Editorial matter, selection and Chapter $1 \odot$ John Singleton and Mary Luckhurst 1996; Chapter 2 (C) Liz Allen; Chapter 3 @ John Singleton and Geoff Sutton; Chapter 4 ( ) Ailsa Cox; Chapter 5 (C) John Singleton; Chapter 6 (C) Elizabeth Baines; Chapter 7 @ John Lennard; Chapter 8 (C) Mary Luckhurst; Chapter 9 (c) Mary Luckhurst and Betty Princep; Chapter 10 ( ) Liz Cashdan, Mary Luckhurst and John SingletoN 1996

All rights reserved. No reproduction, copy or transmission of this publication may be made without written permission.

No paragraph of this publication may be reproduced, copied or transmitted save with written permission or in accordance with the provisions of the Copyright, Designs and Patents Act 1988, or under the terms of any licence permitting limited copying issued by the Copyright Licensing Agency, 90 Tottenham Court Road, London W1P 9HE.

Any person who does any unauthorised act in relation to this publication may be liable to criminal prosecution and civil claims for damages.

First published 1996 by MACMILLAN PRESS LTD

Houndmills, Basingstoke, Hampshire RG21 6XS

and London

Companies and representatives throughout the world

ISBN 978-0-333-64226-9 ISBN 978-1-349-13814-2 (eBook)

DOI $10.1007 / 978-1-349-13814-2$

A catalogue record for this book is available from the British Library.

$\begin{array}{llllllllll}10 & 9 & 8 & 7 & 6 & 5 & 4 & 3 & 2 & 1\end{array}$

$\begin{array}{llllllllll}05 & 04 & 03 & 02 & 01 & 00 & 99 & 98 & 97 & 96\end{array}$ 


\section{Contents}

How to Use this Book

vii

1 Making a Mark

1

JOHN SINGLETON AND MARY LUCKHURST

2 The Workshop Way

18

LIZ ALLEN

3 Words Words Words

41

JOHN SINGLETON AND GEOFF SUTTON

4 Writing the Self

77

AILSA Cox

5 The Short Story

100

JOHN SINGLETON

129

6 Innovative Fiction and the Novel ELIZABETH BAINES

7 Writing to Form - Verse

164 JOHN LENNARD

8 Writing for Performance - Stage, Screen and Radio 201 MARY LUCKHURST

9 Journalistic Writing

MARY LUCKHURST AND BETTY PRINCEP

10 Editing and Rewriting

Liz Cashdan, Mary LuckHuRst and JOHn Singleton

Recommended Reading

Biographical Notes

Acknowledgements 


\section{How to Use This Book}

If you are following a creative writing course, or belong to a creative writing group or are writing on your own you will find this book essential reading. It's about learning the craft of writing. It is not a textbook. Neither is it a 'How To' book. It doesn't tell you what to do. We don't believe in prefabricated writing assembled from step-by-step instructions.

What we do believe is that the imagination drives writing and that it is most effective when harnessed to craft. We feel writers come to good writing in different ways but the best way to improve is by constant practice; by trying out and experimenting with new forms and strategies; by rewriting. So what this book offers is not writing-by-numbers but a whole variety of suggestions and ideas for every kind of writing you can imagine. It's a rich resource book packed with possibilities.

Most taught creative writing goes on in practical group sessions. This book shows you how to get the best out of such workshops and how to build on that experience by developing your writing in your own time.

We believe good readers make good writers so we have recommended hundreds of books and authors for you to select, browse through and learn from. Accomplished writers read as well as write because they've learnt their craft by imitating the good practice of others. Writing is something you can catch through reading.

The Handbook is sequenced and the chapters take you through each stage of the writing process from first acquiring basic skills with words, finding ideas and developing 
them through different forms and genres to the final crafting stages of revision and editing. But don't feel you have to work your way through it systematically. Pick and mix. Select from it what appeals. Adapt the material to suit your needs.

We feel strongly that writers should not work in intellectual isolation. So, Chapter 1 considers some general issues of practice and theory and puts writing in a broad cultural, historical and ideological context. Each of the subsequent chapters starts with a short discussion on aspects of language and genre and is followed by a workshop section where up to ten workshops are described in detail. You can use them to structure your own course with a small group of friends or follow them as part of a taught school, university or community writing programme. The third and final section of each chapter offers you a whole range of writing suggestions to try out in your own time. Some of them could be workshopped as well. The point is you use the book the way you want. 